\title{
Pengaruh Penambahan Tepung Daun Kelor pada Ransum terhadap Kandungan Nutrisi dan Fisik Telur Itik
}

\author{
The Effect of Additional Moringa Leaf Meal (Moringa oleifera) on Feed in Nutritional and Physical Egg \\ Quality of Duck \\ M. Indriati*, \& E. Yuniarsih \\ Program Studi Teknologi Pangan, Fakultas Teknologi dan Informatika, Universitas Mathla'ul Anwar \\ Jl. Raya Labuan KM. 23 Cikaliung Saketi Kabupaten Pandeglang Banten \\ *Corresponding author: marlinda.indriati87@gmail.com
}

(Received 15-12-2020; Revised 19-01-2021; Accepted 27-01-2021)

\begin{abstract}
The aim of this study were to analyzed effect of adding Moringa leaf meal on feed in egg quality of duck. The livestock used were 27 ducks with 3 treatments and 3 replication and each replication there were 3 ducks. P0 (feed + 0\% Moringa), P1 (feed + 5\% Moringa) and P2 (feed + 10\% Moringa). Experimental design used completely randomized design. Variables observed in this study were physical quality such as egg weight and yolk color score and chemical quality such as cholesterol and protein level. Observation was carried out after 4 weeks of feed treatment. Significantly different result were seen in egg weight variables $(\mathrm{P}<0.05)$, treatment of $5 \%$ and $10 \%$ moringa leaf in feed significanty decrease weight of eggs. Adding 5\% and 10\% moringa leaves increased a yolk color score, respectively $7.11+1.05$ and $7.44+$ 0.52 compared with control $6.55+3.20$. Cholesterol levels decrease in $5 \%$ feed treatment $14.07+2.07$ compared to control $15.46+1.43$. The adition of $5 \%$ and $10 \%$ moringa leaves increased protein level $\mathbf{1 0 . 9 0 \%}$ and $\mathbf{1 0 . 8 6 \%}$ respectively, compared to control $10.74 \%$. However, base on statistical analysis of yolk color score, cholesterol and protein levels were not significantly different $(\mathrm{P}>0.05)$.
\end{abstract}

Keywords: moringa leaf, duck, cholesterol, egg

\begin{abstract}
ABSTRAK
Penelitian ini bertujuan untuk menganalisis pengaruh penambahan tepung daun kelor dalam ransum terhadap kualitas telur itik. Ternak yang digunakan sebanyak 27 ekor itik dengan 3 perlakuan dan 3 ulangan yang masing-masing ulangan terdiri dari 3 ekor itik. P0 (ransum $+0 \%$ daun kelor), P1 (ransum $+5 \%$ daun kelor) dan $\mathrm{P2}$ (ransum $+\mathbf{1 0 \%}$ daun kelor), rancangan percobaan yang digunakan adalah rancangan acak lengkap (RAL). Peubah yang diamati dalam penelitian ini adalah kualitas fisik berupa bobot telur dan skor warna kuning telur dan kualitas kimia berupa kadar kolesterol dan protein. Pengamatan kualitas fisik dan kimia telur itik dilakukan setelah 4 minggu perlakuan ransum. Hasil berbeda nyata terlihat pada peubah bobot telur itik $(\mathrm{P}<0.05)$ yaitu perlakuan $5 \%$ dan $10 \%$ daun kelor menurunkan bobot telur itik. \%. Pemberian tepung daun kelor $\mathbf{5 \%}$ dan $\mathbf{1 0 \%}$ meningkatkan nilai skor warna kuning telur masing-masing $7.11+1.05$ dan $7.44+0.52$ dibanding kontrol 6.55 + 3.20. Kadar kolesterol telur turun pada perlakuan 5\% sebesar $14.07+2.07$ dibanding kontrol 15.46 +1.43 . Perlakuan penambahan $5 \%$ dan $\mathbf{1 0 \%}$ daun kelor menaikan kadar protein masing-masing $\mathbf{1 0 . 9 0 \%}$ dan $10.86 \%$ dibandingkan dengan kontrol sebesar $10,74 \%$. Namun berdasarkan analisis statistik peubah skor warna kuning telur, kadar kolesterol dan protein tidak berbeda nyata $(\mathbf{P}>0.05)$.
\end{abstract}

Kata kunci: daun kelor, itik, kolesterol, telur 


\section{PENDAHULUAN}

Telur menjadi sumber utama pemenuhan kebutuhan protein hewani di Indonesia dibandingkan daging dan susu. Tahun 2014, konsumsi daging, susu, dan telur per kapita di Indonesia sebanyak $5067 \mathrm{~kg}, 7131 \mathrm{~kg}$, dan $15277 \mathrm{~kg}$ (Dirjen PKH 2015). Penduduk Indonesia lebih banyak mengonsumsi telur karena telur lebih mudah diperoleh dan relatif murah jika dibandingkan bahan pangan hewani lainnya. Unggas penghasil telur diantaranya adalah ayam, itik, dan puyuh, elama ini masyarakat lebih memilih mengonsumsi telur ayam dibandingkan telur itik dan puyuh.

Telur itik ini memiliki kelemahan yaitu memiliki lemak dan kolesterol yang lebih tinggi dibandingkan telur ayam. Menurut Djarijah (1996), telur itik mengandung $14.7 \mathrm{~g}$ lemak100 g-1 telur dan telur ayam mengandung $11.5 \mathrm{~g}$ lemak $100 \mathrm{~g}-1$ telur. Kolesterol telur itik sebesar 884 mg100g-1 kuning telur (Safitri 2007) sedangkan kolesterol telur ayam sebesar $423 \mathrm{mg} / 100 \mathrm{~g}$ kuning telur (Suprijatna et al. 2005).

Penduduk Indonesia saat ini mencemaskan kandungan kolesterol telur yang tinggi, padahal konsumsi kolesterol dalam jumlah banyak hanya akan meningkatkan kadar low density lipoportein (LDL) jika dikonsumsi oleh orang yang hyper-responders. Farrel (2014) dari Poultry Departement Review FAO, menyatakan pada artikel ulas baliknya bahwa plasma LDL tidak berubah pada hypo-responders dengan mengkonsumsi 21 butir orang-1 minggu-2 atau 3 butir orang-1 hari-2. Kelebihan kolesterol atau LDL di tubuh hanya akan terjadi pada hyperresponders. Berlebihnya kadar kolesterol dalam tubuh menyebabkan berbagai macam penyakit yang berbahaya berupa aterosklerosis yaitu penyempitan atau pengerasan pembuluh darah (LIPI 2010).

Kelor merupakan tanaman yang sangat mudah tumbuh di berbagai daerah dan dapat dikembangbiakkan secara vegetatif (stek) maupun generatif (benih). Sebagai tanaman legum, kelor dapat digunakan sebagai sumber pakan yang baik bagi ternak. Hal ini karenadaun kelor telah dilaporkan menjadi sumber pangan yang kaya $\beta$-karoten, protein, vitamin $\mathrm{C}$, kalsium, kalium, dan menjadi sumber makanan yang baik sebagai antioksidan alami karena adanya berbagai jenis senyawa antioksidan seperti asam askorbat, flavonoid, fenolat dan karotenoid (Krisnadi 2015).

Tepung daun kelor memiliki kandungan protein sebanyak $26.67 \%$ dalam keadaan $100 \%$ bahan kering sehingga dapat menjadi bahan pakan sumber protein sehingga diharapkan dapat pula meningkatkan kandunga protein dalam telur itik. Beta karoten merupakan provitamin A dan pewarna alami kuning telur. Selain itu, $\beta$-karoten juga berfungsi sebagai senyawa antioksidan. Senyawa antioksidan yang terkandung dalam kelor dapat digunakan untuk menurunkan kadar kolesterol telur itik yang tinggi. Aktioksidan dapat mencegah oksidasi lipid (Einsenbrand 2005). Penggunaan produk kaya karotenoid seperti $\beta$-karoten dalam ransum unggas dapat menghasilkan telur rendah kolesterol (Efandi 2011).

Kandungan zat-zat aktif dari daun kelor diharapkan dapat meningkatkan performa dan kualitas produk ternak yang dihasilkan. Daun kelor memiliki provitamin $\mathrm{A}$, vitamin $\mathrm{B}$, vitamin $\mathrm{E}$ (5.63-6.53 $\left.\mathrm{mg} \mathrm{g}^{-1}\right)$, vitamin $\mathrm{C}$ (5.81$\left.6.60 \mathrm{mg} \mathrm{g}^{-1}\right)$, fenolik (36.02-45.81 $\mathrm{mg} \mathrm{g}^{-1}$ ), flavonoid (15$27 \mathrm{mg} \mathrm{g}^{-1}$ ), dan mineral terutama zat besi (Simbolan et al. 2007 dan Sreelatha dan Padma 2009). Daun kelor juga mengandung beberapa senyawa aktif seperti saponin sebesar $1.46 \%$, terpenoid $2.84 \%$, glikosida $0.36 \%$, steroid $3.21 \%$, karatenoid $1.16 \%$ dan tanin $9.36 \%$ (Nweze et al. 2014).

Oleh karena itu perlu dilakukan penelitian penambahan tepung daun kelor ke dalam ransum itik yang diharapkan dapat menurunkan kandungan kolesterol, meningkatkan kadar protein, performa skor warna, dan bobot telur itik. Tujuan dari penelitian ini adalah untuk mengetahui pengaruh penambahan tepung daun kelor pada ransum itik terhadap kandungan kolesterol, protein, skor warna kuning telur dan bobot telur itik.

\section{MATERI DAN METODE}

\section{Waktu dan Lokasi Penelitian}

Penelitian ini diawali dengan pemeliharaan itik perlakuan di Kecamatan. Panimbang, Kabupaten. Pandeglang-Banten. Analisis fisik dan kimia dilakukan di Sekolah Vokasi Institut Pertanian Bogor dan Unit Laboratorium Jasa Pengujian, Kalibrasi, dan Sertifikasi Kampus IPB Baranang siang. Waktu pelaksanaan dimulai pada Maret - Oktober 2020.

\section{Materi}

\section{Ternak}

Ternak yang digunakan dalam penelitian ini adalah itik tegal umur 19 minggu sebanyak 27 ekor itik betina dan 4 ekor itik pejantan. Itik pejantan digunakan sebagai pemacu itik betina agar bertelur.

\section{Kandang}

Kandang disediakan tempat pakan dan tempat air minum. Peralatan yang digunakan adalah tempat pakan yang terbuat dari bambu, tempat minum, lampu penerangan, timbangan, tangki untuk penyimpanan air berukuran 30 liter, dan ember.

\section{Ransum}

Pakan yang diberikan kepada ternak yaitu pakan komersil berupa ransum komplit untuk ayam fase bertelur. Kandungan nutrien ransum komplit dapat dilihat pada Tabel 1 dan kandungan nutrien pada dry matter tepung daun kelor dapat dilihat pada Tabel 2.

\section{Prosedur}

\section{Pemeliharaan}

Itik sebanyak 27 ekor dengan umur 19 minggu yang terbagi dalam 3 perlakuan dan 3 ulangan dengan masing-masing ulangan terdiri dari 3 itik. Pemberian pakan perlakuan dilakukan selama 4 minggu pemeliharaan.

\section{Peubah yang diamati}

\section{Bobot telur itik}

Pengukuran bobot telur menggunakan timbangan digital dilakukan pada minggu ke-4 pemeliharaan dengan 
Tabel 1. Kandungan Nutrien Ransum Komersil

\begin{tabular}{lc}
\hline \multicolumn{1}{c}{ Nutrien } & Jumlah \\
\hline Bahan Kering (\%) & 87 \\
Protein Kasar (\%) & 17 \\
Serat Kasar (\%) & 6 \\
Lemak Kasar (\%) & 9 \\
Beta-N (\%) & - \\
Abu (\%) & 14 \\
$\mathrm{Ca}(\%)$ & 4 \\
$\mathrm{P}(\%)$ & 0.8 \\
$\mathrm{Na}(\%)$ & - \\
Energi Bruto (kkal kg-1) & - \\
Energi Metabolis $\left(\mathrm{kkal} \mathrm{kg}^{-1}\right)$ & 2850 \\
\hline
\end{tabular}

Tabel 2. Kandungan nutrien pada dry matter tepung daun kelor

\begin{tabular}{lc}
\hline \multicolumn{1}{c}{ Nutrien } & Jumlah \\
\hline Abu & $9.21(\%)$ \\
Protein kasar & $27.67(\%)$ \\
Lemak kasar & $5.61(\%)$ \\
Serat kasar & $16.45(\%)$ \\
Beta-N & $41.05(\%)$ \\
Kalsium & $2.62(\%)$ \\
Fosfor & $0.60(\%)$ \\
Gross Energi & $4817.29\left(\mathrm{Kkal} \mathrm{kg}^{-1}\right)$ \\
\hline
\end{tabular}

Hasil analisis Laboratorium Ilmu dan Teknologi Pakan, fakultas peternakan IPB (2016)

perlakuan pakan. Setelah minggu ke-4 telur dikumpukan setiap hari hingga terkumpul 9 butir dari setiap kandang perlakuan. Setiap kandang perlakuan terdiri dari 3 itik dan 3 ulangan. Total jumlah telur dari seluruh perlakuan sebanyak 27 butir.

\section{Skor warna kuning telur}

Pengukuran skor warna kuning telur menggunakan yolk colour fan dilakukan pada Minggu ke-4, selama pemeliharaan dengan pakan perlakuan. Setelah minggu ke-4 telur dikumpukan setiap hari hingga terkumpul 9 butir dari setiap kandang perlakuan. Setiap kandang perlakuan terdiri dari 3 itik dan 3 ulangan. Total jumlah telur dari seluruh perlakuan sebanyak 27 butir.

\section{Kandungan protein}

Pengukuran kadar protein menggunakan metode kjeldahl dilakukan pada minggu ke-4 pemeliharaan dengan perlakuan pakan. Setelah minggu ke-4 telur dikumpukan setiap hari hingga terkumpul 9 butir dari setiap kandang perlakuan. Setiap kandang perlakuan terdiri dari 3 itik dan 3 ulangan. Total jumlah telur dari seluruh perlakuan sebanyak 27 butir.

\section{Kandungan kolesterol}

Pengukuran kadar kolesterol menggunakan metode HPLC dilakukan pada minggu ke-4 pemeliharaan dengan perlakuan pakan. Setelah minggu ke-4 telur dikumpukan setiap hari hingga terkumpul 9 butir dari setiap kandang perlakuan. Setiap kandang perlakuan terdiri dari 3 itik dan 3 ulangan. Total jumlah telur dari seluruh perlakuan sebanyak 27 butir.

\section{Rancangan percobaan dan analisis data}

Penelitian ini menggunakan tiga ransum perlakuan berdasarkan penambahan tepung daun kelor. Ransum perlakuan dalam penelitian ini adalah:

P0 : Pakan komplit $+0 \%$ tepung daun kelor

P1: Pakan komplit $+5 \%$ tepung daun kelor

P2: Pakan komplit $+10 \%$ tepung daun kelor

Penelitian ini menggunakan Rancangan Acak Lengkap dengan tiga perlakuan dan tiga ulangan yang disusun secara acak untuk seluruh satuan percobaan. Adapun model matematika yang digunakan adalah (Steel dan Torrie 1995):

$$
\mathrm{Yij}=\mu+\tau \mathrm{i}+\varepsilon \mathrm{ij}
$$

Keterangan :

Yij = nilai pengamatan untuk perlakuan yang diberikan

$\mu \quad=$ rataan umum

$\tau \mathrm{i}=$ efek perlakuan ke-i

$\varepsilon \mathrm{ij}=$ eror perlakuan ke-i dan ulangan ke-j

\section{Analisis data}

Data hasil analisa kandungan kolesterol, protein, bobot dan skor warna kuning telur yang diperoleh dianalisis menggunakan analysis of variance (ANOVA) dan jika terdapat perbedaan nyata, maka dilakukan uji lanjut Duncan.

\section{HASIL DAN PEMBAHASAN}

\section{Kualitas Fisik Telur Itik}

Pengaruh penambahan tepung daun kelor (Moringa olefera) terhadap kualitas fisik telur itik yang diamati pada penelitian ini meliputi bobot telur dan skor warna kuning telur itik, telur yang dikoleksi merupakan hasil pemeliharaan dengan perlakuan pada minggu ke 4 - 6 . Telur yang dikoleksi kemudian diukur peubah yang diamati sesuai dengan metode yang dilaksanakan pada penelitian ini. Data kualitas fisik telur itik disajikan pada Tabel 3.

Berdasarkan data dari Gambar 1 terlihat bahwa dengan adanya penambahan tepung daun kelor dalam ransum itik yang berbeda $(0 \%, 5 \%, 10 \%)$ menyebabkan penurunan bobot telur itik yang dihasilkan. Hal ini dibuktikan dengan hasil analisa sidik ragam yang menunjukan hasil yang nyata antara penambahan persentase tepung daun kelor berpengaruh terhadap penurunan bobot telur itik $(\mathrm{P}<0.05)$. Perlakuan terhadap ransum pada penelitian ini berpengarug terhadap bobot telur itik yang dihasilkan hal ini sejalan dengan penelitian yang dilakukan Sarwono (2001) menyatakan bahwa berat telur dipengaruhi beberapa faktor yaitu : umur itik, perubahan musim, berat tubuh induk dan ransum yang diberikan.

Berdasarkan hasil penelitian menurunnya bobot telur itik seiring dengan penambahan persentase perlakuan daun kelor dikarenakan semakin tingginya kandungan antinutrisi yakni senyawa tanin saponin yang ada pada tepung daun kelor. Eishu (2005) melaporkan tanin 
Indriati et al.

Jurnal Ilmu Produksi dan Teknologi Hasil Peternakan 9 (1): 42-48

Tabel 3. Kualitas fisik telur itik dengan perlakuan penambahan tepung daun kelor pada ransum.

\begin{tabular}{lcccc}
\hline \multirow{2}{*}{ Peubah } & \multicolumn{3}{c}{ Perlakuan Tepung Daun Kelor } & \multirow{2}{*}{ Rataan } \\
\cline { 2 - 4 } & $0 \%$ & $5 \%$ & $10 \%$ & $67.26 \pm 5.39$ \\
\hline Bobot Telur & $73.78 \pm 6.62 \mathrm{a}$ & $65.77 \pm 5.33 \mathrm{~b}$ & $62.22 \pm 4.23 \mathrm{~b}$ & $7.03 \pm 1.59$ \\
Skor Warna Kuning Telur & $6.55 \pm 3.20 \mathrm{a}$ & $7.11 \pm 1.05 \mathrm{a}$ & $7.44 \pm 0.52 \mathrm{a}$ & 7.05 \\
\hline
\end{tabular}

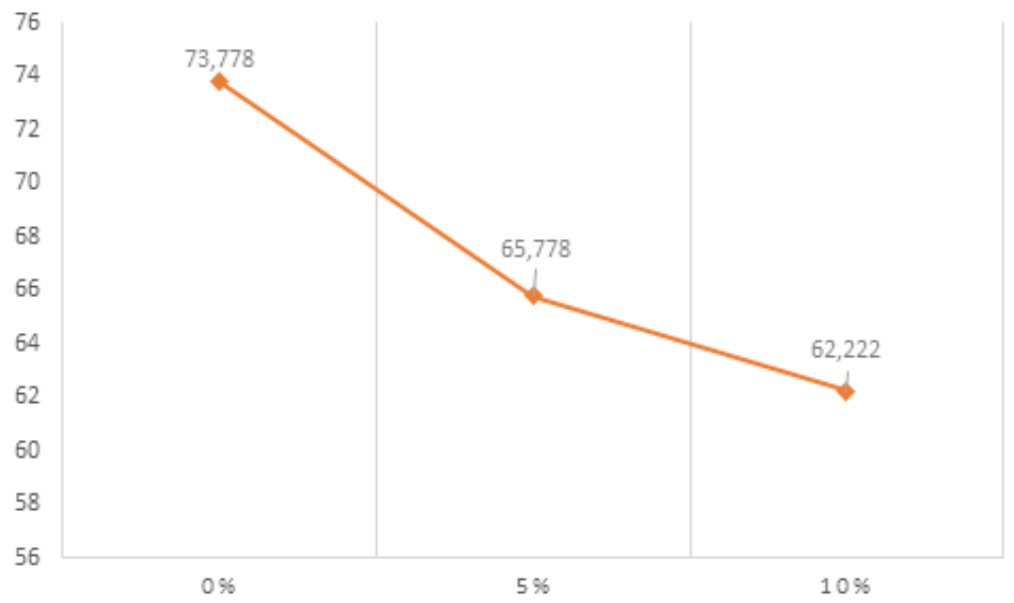

Gambar 1. Rataan bobot telur itik dengan perlakuan penambahan daun kelor pada ransum

merupakan senyawa antinutrisi yang dapat membentuk kompleks dengan protein selama di dalam usus halus, akibatnya protein tidak dapat didegradasi menjadi produk turunannya seperti asam-asam amino dan peptida serta tidak diabsorbsi oleh sel-sel usus halus, terutama pada unggas yang tergolong dalam hewan monogastrik.

Hal ini sejalan dengan pendapat Widowati et al. (2010) yang menyebutkan bahwa kandungan senyawa tanin dalam pakan dapat menghambat beberapa enzim pencernaan, diantaranya enzim tripsin, amilase, dan lipase yang menyebabkan menurunnya ketersediaan protein yang digunakan untuk mendukung proses pembentukan telur. Lebih jauh Wahyudi et al. (2015) melaporkan saponin selain sebagai inhibitor enzim juga memiliki potensi dapat berikatan dengan reseptor yang terhubung oleh protein transporter pada membran sel-sel usus halus. Akibat terjadinya ikatan tersebut terjadi gangguan transport protein atau absorbsi asam amino hasil pencernaan.

Berdasarkan Gambar 2 rataan skor warna kuning telur memperlihatkan bahwa dengan adanya perlakuan penambahan tepung daun kelor pada ransum $(0 \%, 5 \%$, $10 \%)$ memperlihatkan terjadinya peningkatan skor warna kuning telur walaupun secara statistik tidak menunjukkan pengaruh perbedaan yang nyata pada analisis sidik ragam. Di pasaran konsumen lebih menyukai warna kuning telur itik yang lebih mendekati orange. Warna kuning telur secara fisik menentukan kualitas telur itik dari sudut pandang konsumen. Warna kuning telur dapat menentukan senyawa

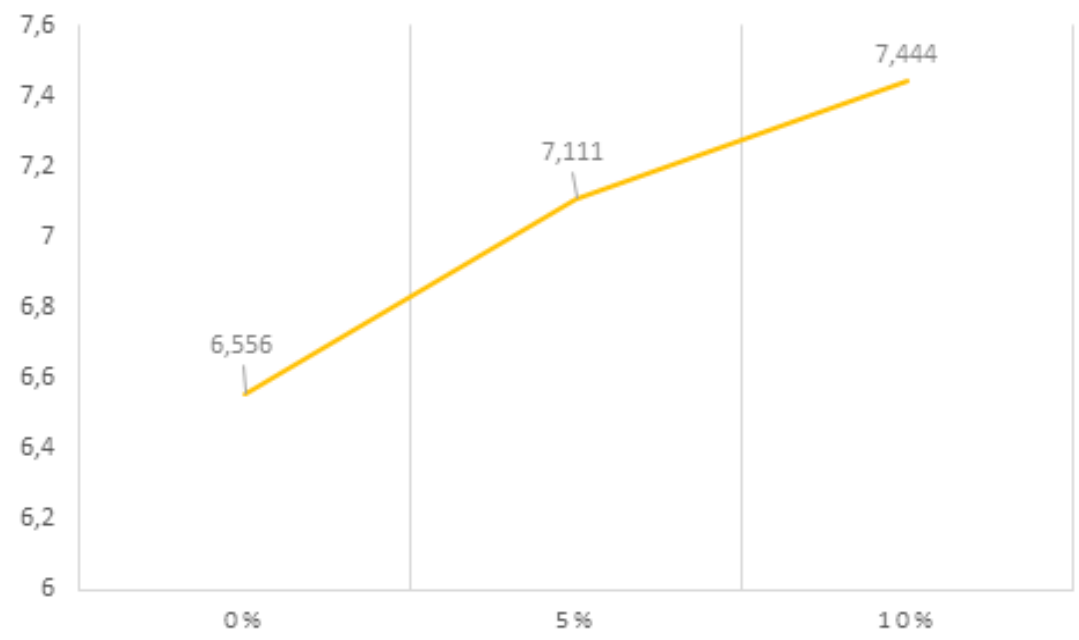

Gambar 2. Rataan skor warna kuning telur itik dengan perlakuan penambahan daun kelor pada ransum 
yang terkandung didalamnya. Skor warna kuning telur yang baik apabila mencapai skor 7-8 skala roche, maka telur akan digolongkan ke dalam kualitas baik menurut Amrullah (2003). Sujana (2006) menyatakan bahwa pakan mempengaruhi warna kuning telur, yaitu bahan pakan yang mengandung pigmen karotenoid terutama pigmen beta-karoten dan xantofil. Menurut Krisnadi (2015) kelor mengandung $4208 \mu \mathrm{g}$ beta karoten dalam 100 gram daun keringnya dan 4 kali lebih banyak dibandingkan wortel, sedangkan jagung kuning mengandung karetonoid berkisar 6.4-11.3 $\mu \mathrm{g} / \mathrm{g}$ sehingga kandungan karoten pada kelor lebih tinggi 4-6 kali kandungan karoten jagung. Sumber lain berdasarkan penelitian Wiradimadja et al. (2010) penggunaan tepung daun kelor sebanyak $5 \%$ pada ransum dapat memberikan warna kuning telur 10.04 skala roche. Selain pengaruh kandungan daun kelor pada perlakuan pakan, bahan pakan lain yang mempengaruhi skor warna kuning telur adalah jagung dan kedelai yang terdapat didalam pakan komersil. Berdasarkan hasil penelitian Suhada (2016) penggunaan 51\% jagung sebagai sumber xantofil dalam ransum pada umumnya tidak cukup untuk memenuhi kebutuhan xantofil sehingga mencapai kualitas warna kuning telur yang baik, oleh karena itu perlu penambahan tepung daun kelor dalam ransum.

\section{Kualitas Kimia Telur Itik}

Selain kulitas fisik pada penelitian ini dilakukan pula pengamatan kualitas kimia telur itik yang telah pendapatkan perlakuan penambahan tepung daun kelor pada ransum. Adapun parameter kimia yang diamati yaitu kadar kolesterol, lemak dan protein. Data Analisa kualitas kimia telur itik disajikan pada Tabel 4.
Hasil penelitian Kasmirah et al. (2012) memperoleh kadar kolesterol telur itik 12.82-15.35 mg g-1 kuning telur. Berdasarkan Gambar 3 pada parameter kandungan kolesterol terlihat bahwa penambahan 5\% daun kelor terbukti menurukan kadar kolesterol telur itik. Perlakuan pakan kontrol menghasilkan telur dengan kandungan kolesterol $15.46 \%$ sedangkan pada perlakuan tepung daun kelor 5\% kadar kolesterol telur itik $14.07 \%$. Penurunan ini terjadi karena daun kelor mengandung banyak senyawa antioksidan yang dapat berperan dalam menghambat proses terbentuknya kolesterol. Menurut Anwar et al. (2005) daun kelor banyak mengandung antioksidan alami seperti asam askorbat, flavonoid, fenolat dan karoteniod. Antioksidan adalah senyawa yang dapat mendonorkan elektronnya (pemberi atom hydrogen) kepada radikal bebas, sehingga menghentikan reaksi berantai, dan mengubah radikal bebas menjadi bentuk yang stabil. Antioksidan bersifat sangat mudah dioksidasi sehingga radikal bebas akan mengoksidasi antioksidan dan melindungi molekul lain didalam sel dari kerusakan akibat oksidasi oleh radikal bebas (Werdhasari 2014).

Namun kandungan kolesterol telur itik naik pada perlakuan tepung daun kelor $10 \%$ menjadi $17.07 \%$ hal ini kemungkinan disebabkan karena kandungan yang terdapat pada daun kelor yaitu asam lemak yang juga mempengaruhi peningkatan kadar kolesterol pada telur itik. Menurut Sulistyowati (2016) struktur kimia dasar kolesterol berupa steroid. Terdapat dalam jaringan dan lipoprotein plasma dalam bentuk kolesterol bebas atau gabungan dari asam lemak rantai panjang sebagai ester kolesterol. Hal ini yang menyebabkan kandungan kolesterol telur itik meningkat

Tabel 4. Kualitas kimia telur itik dengan perlakuan penambahan tepung daun kelor pada ransum.

\begin{tabular}{lcccc}
\hline \multirow{2}{*}{ Peubah } & \multicolumn{3}{c}{ Perlakuan Tepung Daun Kelor } & \multirow{2}{*}{ Rataan } \\
\cline { 2 - 4 } & $0 \%$ & $5 \%$ & $10 \%$ & $10.83 \pm 0.47$ \\
\hline Protein & $10.74 \pm 0.48 \mathrm{a}$ & $10.90 \pm 0.45 \mathrm{a}$ & $10.86 \pm 0.48 \mathrm{a}$ & $15.52 \pm 1.29$ \\
Kolesterol & $15.46 \pm 1.43 \mathrm{a}$ & $14.07 \pm 2.07 \mathrm{a}$ & $17.04 \pm 0.38 \mathrm{a}$ & 152 \\
\hline
\end{tabular}

Kolesterol merupakan zat alami yang terdapat dalam tubuh yang diperlukam untuk proses-proses penting dalam tubuh, baik untuk manusia maupun ternak. Kolesterol juga dibutuhkan untuk perkembangan embrio ungags sehingga kolesterol harus disimpan di dalam telur. Kandungan kolesterol telur adalah $0.548 \mathrm{mg} 100 \mathrm{~g}^{-1}$ dan pada kuning telur adalah $1.602 \mathrm{mg} 100 \mathrm{~g}^{-1}$. Kuning telur mengandung kolesterol yang tinggi sedangkan putih telur tidak mengandung kolesterol (Piliang dan Djojosoebagio 2006).

Biosintesis kolesterol pada itik petelur terjadi di hati. Biosintesis kolesterol berlangsung dalam tiga fase. Fase pertama, unit-unit asetil KoA berkondensasi membentuk mevalonat. Fase kedua mevalonat diubah menjadi unitunit isoprene 5-karbon yang mengalami fosforilasi dan berkondesasi membawa senyawa 30-karbon, yaitu skualen mengalami siklisasi membentuk lanosterol yang memiliki cincin-cincin inti steroid. Lanosterol mengalami modifikasi melalui serangkaian reaksi untuk membentuk kolesterol (Marks et al. 2000). pada perlakuan $10 \%$ akibat penambahan kandungan asam lemak yang terdapat pada daun kelor. Meskipun berdasarkan analisis sidik ragam penambahan perlakuan daun kelor pada ransum itik tidak memberikan pengaruh yang nyata terhadap kandungan kolesterol telur itik $(\mathrm{P}>0.05)$.

Selain faktor antioksidan, kadar serat kasar pada tepung daun kelor juga dapat menurunkan kandungan kolesterol pada telur itik. Hal ini berdasarkan hasil penelitian Aan (2011) yang menyatakan rendahkan kadar kolesterol disebabkan oleh kadar serat kasar yang tinggi pada ransum sebesar 14\%. Berdasarkan penelitian yang dilakukan oleh Suharyati (2016) penggunaan ransum dengan serat kasar $3-4 \%$ tidak berpangaruh nyata pada kadar kolesterol darah. Serta hasil penelitian ini pun didukung oleh penyataan Atsilah (2016) dalam penelitiannya yang menyatakan tidak terjadi pengaruh yang nyata dari pemberian daun kelor sebanyak 5-10\% terhadap kadar kolesterol pada telur.

Laporan penelitian Mulo et al. (2012) menyatakan bahwa daun kelor memiliki kandungan protein yang tinggi 


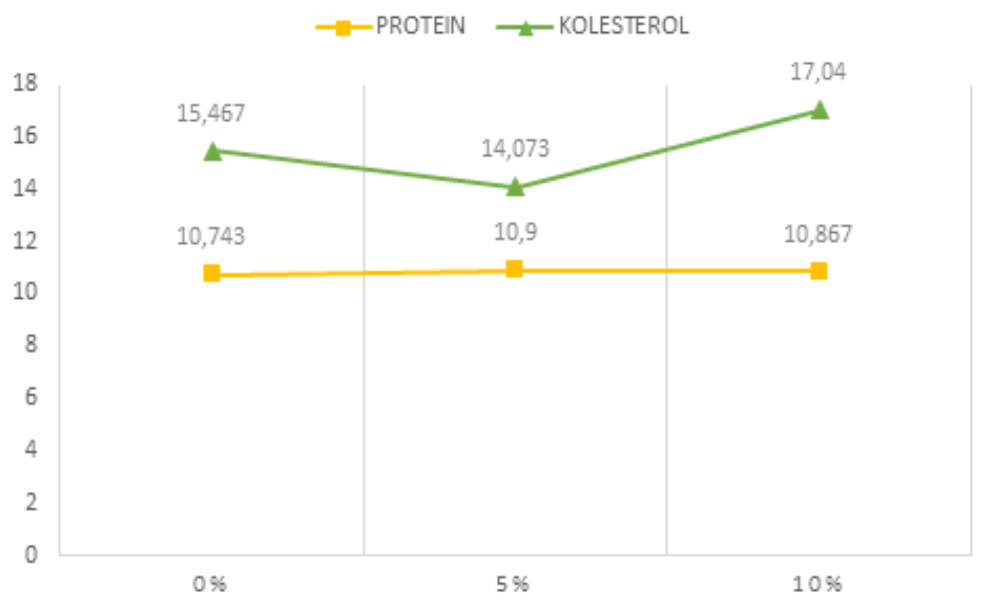

Gambar 3. Rataan kandungan kolesterol dan protein telur itik dengan perlakuan penambahan daun kelor pada ransum

mencapai $28.44 \%$. Tingginya kandungan protein pada daun kelor ini memberikan dampak meningkatkan kadar protein telur itik pengging dalam kondisi proses pencernaan dan metabolisme yang normal. Daun kelor (Moringa oleifera) sangat kaya akan nutrisi, salah satunya adalah protein (Misra 2014). Menurut Soetanto (2005) daun kelor memiliki kandungan protein yang dapat mencapai 43\%. Kadar protein yang cukup tinggi pada daun kelor juga dinyatakan oleh Teizeira (2014).

Berdasarkan Gambar 3 untuk parameter kandungan protein terlihat bahwa dengan penambahan tepung daun kelor 5\% dan 10\% menaikkan kadar protein dari $10.74 \%$ pada perlakuan kelor $0 \%$, menjadi $10.90 \%$ pada perlakuan $5 \%$ dan $10.86 \%$ pada perlakuan $10 \%$ walaupun berdasarkan hasil analisis sidik ragam tidak menunjukan hasil yang berbeda nyata $(\mathrm{P}>0.05)$. Hal ini sesuai dengan penelitian Rosida et al. (2019) menyatakan, kadar protein telur itik pengging pada penelitian tersebut menunjukkan hasil yang tidak berbeda nyata antara perlakuan dengan kontrol $(0 \%)$. Kondisi ini menunjukan bahwa imbuhan tepung daun kelor pada berbagai konsentrasi $(2.5 \%, 5 \%, 7.5 \%$, dan $10 \%)$ tidak dapat meningkatkan kadar protein total telur itik pengging. Kemungkinan lain adalah komponen bioaktif yang terkandung dalam tepung daun kelor hingga 10\% belum dapat mempengaruhi metabolisme protein pada itik penelitian.

Pada penelitian ini kisaran kadar protein dengan perlakuan pakan daun kelor yaitu antara 10.74-10.90\%, hal ini sesuai dengan penelitian Rosida et al. (2019) kandungan kadar protein telur itik dengan perlakuan pakan daun kelor yaitu antara 9.24-15.88\%. Ganesan et al. (2014) menyatakan kisaran kandungan protein dengan penambahan tepung daun kelor antara 9.30-11.80\%. Jika dicermati, kandungan protein telur pada penelitian cenderung meningkat seiring dengan peningkatan kadar tepung daun yang diberikan. Berdasarkan hasil penelitian dan studi literatur menunjukkan bahwa dengan panambahan daun kelor dapat meningkatkan kandungan protein pada telur meskipun secara statistik tidak menunjukkan hasil yang berbeda.

\section{KESIMPULAN}

Penambahan tepung daun kelor dalam ransum itik berpengaruh nyata terhadap parameter bobot telur itik dengan adanya peningkatan persentase tepung daun kelor dalam ransum menyebabkan penurunan bobot telur itik. Parameter kandungan kolesterol, protein, dan skor warna kuning telur berdasarkan analisis statistik tidak menunjukan hasil yang berbeda nyata.

\section{DAFTAR PUSTAKA}

Aan. 2011. Pengaruh pemberian tepung daun katuk (Sauropus androgynus) dan murbei (Morus sp.) terhadap serum kolesterol dan hormon progesteron pada puyuh. Skripsi. Institut Pertanian Bogor, Bogor.

Amrullah, I. K. 2003. Nutrisi Ayam Petelur. Satu Gunung budi press, Bogor.

Anwar, F., M. Ashraf, \& M. I. Bhanger. 2005. Interprovenance variation in the composition of Moringa oleifera oil seeds from Pakistan. J Am Oil Chem Soc. 82:45-51.

Atsilah, I. 2016. Performa, persentase bobot karkas dan organ dalam puyuh (Coturnix coturnix japonica) yang diberi ransum tepung daun kelor (Moringa oleifera) dan asam fulvat. Skripsi. Institut Pertanian Bogor, Bogor.

Eishu, R. I. 2005. Effect of diettary protein level on production and characteristic of japanase quail egg. The Journal of Poultry Science. 42(2):130-139.

Ganesan, P., T. Kaewmanee, S. Benjakul, \& B. S. Baharin. 2014. Comparative Study on the Nutritional Value of Pi Dan and Salted Duck Egg. J. Food Sci. 34(1):1-6.

Kasmirah, D., Y. Fenita, \& U. Santoso. 2012. Pengaruh penggunaan tepung daun katuk (Sauropus androgynus) terhadap kadar kolesterol telur itik mojosari (Anas javanica). Jurnal Sain Peternakan Indonesia. 8(2): 7786. 
Krisnadi, A. D. 2015. Kelor Super Nutrisi. Blora Pusat Infromasi dan PengembanganTanaman Kelor Indonesia. Blora (ID): Pusat Informasi dan Pengembangan Tanaman Kelor Indonesia, Lembaga Swadaya Masyarakat Media Peduli Lingkungan.

Marks, H. L., \& K. W. Washburn. 2000. Egg yolk cholesterol lowering effect of garlic and tea. Journal of Bioscience. 8: 456-460.

Mirsa, A. 2014. Evaluation of anti diarrheal potential of Moringa oleifera leaves. Journal of Pharmocognosy and Phytochemistry. 2(5): 43-36.

Mulo, P., I. Sakurai, \& E. M. Aro. 2012. Strategies for Psba Gene Expression in Cyanobacteria, Green Algae and Higher Plants: from Transcription to PSII Repair. Biochim Biophys Acmardta. 1817: 247-257.

Piliang, W. G., \& S. Djojosoebagio. 2002. Fisiologi Nutrisi Volume I. Edisi ke-2. Institut Pertanian Bogor (IPB) Press, Bogor.

Sarwono, B. 2001. Pengawetan \& Pemanfaatan Telur. Cetakan ke delapan. Penebar Swadaya. Jakarta.

Soetanto, H. 2005. Potensi tanaman kelor (Moringa oleifera, Lam) sebagai sumber pakan dan pangan di Indonesia. Prosiding Seminar AINI V. Universitas Brawijaya, Malang.

Suhada, S. 2016. Pengaruh Penggunaan Tepung Daun Kelor (Moringa oleifera) dan Asam Fulfat Terhadap Kualitas Telur Puyuh. Skripsi. Institut Pertanian Bogor, Bogor.

Suharyati. 2016. Evaluasi pemberian asam fulvat dengan tepung daun kelor terhadap hematologi dan profil lipid puyuh periode petelur. Skripsi. Institut Pertanian Bogor, Bogor.
Sujana, E., S. Wahyuni, \& H. Buhanuddin. 2006. Efek pemberian ransum yang mengandung tepung daun singkong, daun ubi jalar dan eceng gondok sebagai sumber pigmen karotenoid terhadap kualitas kuning telur itik tegal. J Ilmu Ternak. 6(1):53-56.

Sulistyowati, Y. 2016. Pengaruh pemberian ikopen terhadap status antioksidan (vitamin $\mathrm{C}$ vitamin $\mathrm{E}$ dan gluthathion peroksidase) tikus (Rattus norvegicus galur Sprague Dawley) hiperkolesterolmik. Tesis. Program Studi Magister Ilmu Biomedik. Universitas Diponegoro, Semarang .

Teizeira, C. M. L. L., F. V. Kirste, \& P. C. N. Teixeira. 2014. Evaluation of biodiesel producer microalgae. J. Appl. Phycol. 24: 557-563.

Wahyudi, I. 2015. Pengaruh pemberian ekstrak daun binahong (Anredera cordifolia (ten) steenis) dalam air minum terhadap bobo hidup, bobot karkas dan giblet broiler: Jurnal Ilmiah Peternakan Terpadu. 3(2): 20-26.

Werdhasari, A. 2014. Peran antioksidan pada kesehatan. Jurnal Biotek Medisiana Indonesia. 3(2):59-68.

Widowati, S. 2010. Proses Pembuatan dan Karakterisasi Nasi Sorgum Instan: Jurnal Prosiding Pekan Serealia Nasional ISBN : 978-979-8940-29-3.

Wiradimadja, R., H. Burhanuddin, \& D. Saefulhadjar. 2010. Peningkatan kadar vitamin A pada telur ayam melalui penggunaan daun katuk (Sauropus androgynus L.Merr) dalam Ransum. J Ilmu Ternak. 10 (2):90-94. 